\title{
STRATEGIC PLANNING OF THE UNITARY STATE IN CONDITIONS OF DECENTRALIZED BUDGETING
}

\author{
Viktoriya Stolyarova', Vasylyi Stolyarov²
}

\begin{abstract}
The purpose of the article is to deepen the scientific foundations of strategic planning using the provisions of the theory of purposeful reproduction and the principles of systematic methodology. In modern conditions in Ukraine there is an increase in financial self-sufficiency of regions with a simultaneous increase in social responsibility of the Center and Regions for the achievement of balanced and sustainable socio-economic development at different levels of management. The main objectives of the study were as follows: clarification of challenges and problems of strategic planning; disclosure of the essence and content of strategic planning in a unitary state; system classification of purposeful reproduction processes at different levels of management; rationale for the limits of budgetary centralism with budgetary federalism in the harmonious proportions of the "golden section"; defining the powers of Central and Regional authorities in the strategic planning of a sovereign state. The research methodology was based on the following methods: historical, dialectical, structural and functional, system analysis and synthesis, hypothetic and deductive, and logical modeling. The subject of the research is the scientific and methodological support of the justification of strategic objectives, priorities and indicators for planning long-term socio-economic development at the national and regional levels of management in terms of decentralized budgeting. The powers of the Central and Regional executive bodies are based on the provisions and principles of state formation on the basis of coordinated and synchronous interaction of purposeful reproductive processes. The execution of strategic planning processes and procedures by the Center and Regions under decentralized budgeting conditions determines those components of the development of a sovereign, independent, legal, social and unitary state, which are regulated by the volume and structure of the Consolidated State Budget. The establishment of proportions between the state and local budgets of Ukraine within the framework of the Consolidated Budget of the unitary state was carried out using the harmonious proportions of the "Golden Section", which ensures the balanced and systematic functioning of the Center and Regions as a dialectically separated unity. Conclusions. The main result of the study is a methodological approach to determining the competence of the Center and Regions in the strategic planning of socio-economic development on the basis of achieving coherence and synchrony of purposeful reproductive processes of different scales of market economy of the unitary Ukrainian state. The results of the study formed the basis of the scientific paradigm "Stable and sustainable socio-economic development for the Ukrainian people". Implementation. The methodological approach to the strategy of Regions and the Center for socio-economic development of the administrative region and the state as a whole was developed by the Khmelnytskyi Regional State Administration in 2015-2016. Strategic goals and priorities of socio-economic development of Luhansk and Donetsk regions were defined for 2014-2020 as an alternative to the Antiterrorist Operation (ATO), which was conducted from February to August 2014 in the Ukrainian Donbass.
\end{abstract}

Key words: strategic planning, decentralized budgeting, proportions of "Golden overturn".

JEL Classification: R14, D18, P21

\section{Introduction}

According to the 1996 Constitution, Ukraine is a sovereign, independent, legal, social and unitary

\footnotetext{
Corresponding author:

${ }^{1}$ Institute of Physical Economy named after Podolinsky S.A., Ukraine

E-mail: antoshka2007@ukr.net

ORCID: https://orcid.org/0000-0002-9483-5126

${ }^{2}$ Institute of Physical Economy named after Podolinsky S.A., Ukraine

E-mail: stolyarovvf@ukr.net

ORCID: https://orcid.org/0000-0002-4399-7117
}

state. At the beginning of the XXI century state strategic planning was seen as a function of public administration, the choice of priorities, setting 
goals and directions of development, taking into account available resources, the development and implementation of interrelated objectives and measures of socio-economic development.

Regulatory and scientific-methodological support of the national strategy began to form in 2002-2004 through the development of the Strategy of economic and social development of Ukraine for 2004-2015 "Through European integration". The main forecast macroeconomic indicators of the development of Ukraine were considered on March 12, 2004 at the enlarged meeting of the Government and the Presidium of the National Academy of Sciences of Ukraine (NASU) (Galchinsky, Geets, \& others, 2004).

The summary of the Strategy of Economic and Social Development of Ukraine for 2004-2015 "Through European Integration" states that "its essence is to conduct fundamental qualitative transformations in all spheres of public life. The implementation of certain Strategies and tasks will create real preconditions for the acquisition by Ukraine of full membership in the $\mathrm{EU}$, ensure sustainable economic growth, promote an innovative model of development and social reorientation of economic policy" (Galchinsky, Geets, \& others, 2004).

The strategy for the future of Ukraine was based, on the one hand, on the historical experience and peculiarities of society, which are determined by national, cultural and spiritual traditions, and, on the other hand, on the challenges of the XXI century on the future path of development of all civilization.

The main result of the Strategy was a change in the factors of economic growth and reorientation to the ones based on the expansion of domestic consumer and investment demand, strengthening the competitiveness of the national economy, increasing the efficiency of the use of national economic resources.

The implementation of the Strategy in the life of the Ukrainian people was seen as a means of realizing Ukraine's potential advantages in significant scientific and technological potential and developed human capital.

However, the Sustainable Development Strategy "Ukraine - 2020", imposed by international geopolitical business after the events on the second Euromaidan in Kiev (November 2013 - February 2014), violated the values of civilizational and generic historical development and spiritual continuity of generations.
Preparations for the extraordinary election of Ukraine's fifth president, Petro Poroshenko, on January 12, 2015 of the Ukraine 2020 Sustainable Development Strategy lasted less than a year at the same time as the deployment of the AntiTerrorist Operation (ATO) from April to August 2014 in the Ukrainian Donbass.

The Sustainable Development Strategy "Ukraine 2020" was not a continuation of the course "Through European Integration" of the Strategy of Economic and Social Development of Ukraine for 2004-2015 and the State Strategy of Regional Development for the period until 2015 (approved by the Government Decree of July 21, 2006).

The sustainable development strategy "Ukraine 2020" call for the introduction of European standards of living in Ukraine and reaching a leading position in the world. The plan was to move forward on the vectors of development, security, responsibility, and pride, which included 62 reforms and state development programs. 10 reforms and programs were recognized as priority, among which the 5th was decentralization and public administration reform (Sustainable Development Strategy "Ukraine - 2020", 2015).

The Verkhovna Rada (Parliament) of Ukraine twice considered and discussed the draft laws "On State Strategic Planning" in 2011 and 2017. Unfortunately, these draft laws were not finally enacted by Parliament and approved by the President of Ukraine. The expert opinion of the Ukrainian Evaluation Association of Policies, Programs and Projects (UEA) states insufficient ability of draft laws on monitoring and evaluation to influence management decisions to achieve the goal, solve problems and obtain the expected results of state strategies (UEA "Strengthening decentralization in Ukraine" is funded by the National Endowment for Democracy - NED, USA).

Ukraine has gained experience in strategic planning, both through the formation of State Strategies for Regional Development for the periods up to 2015 (9 years) to 2020 (6 years) and 2027 (7 years), and through the development of Activities Plans for their implementation in stages in three years (first stage) and four years (second stage).

The Government Resolution of July 21, 2006 "On Approval of the State Strategy of Regional Development for the period until 2015" was the last one that defined the state priorities in every administrative region of Ukraine. In contrast, Government resolutions of 
06.08.2014 "On Approval of the State Strategy for Regional Development until 2020" and 05.08.2020 "On Approval of the State Strategy for Regional Development until 2027" abolished this nationwide approach to strategic planning, which contributed to the centrifugation of regional development from the core of statehood balanced and systemic socio-economic development of each region and state as a whole.

The Activities Plan for 2015-2017 to implement the State Regional Development Strategy for the period up to 2020 was approved by a government decree of 07.10.2015, that is, 16 months after its acceptance. The Activities Plan for 2018-2020 for the implementation of this Strategy was approved by the Government Resolution of September 12, 2018, on the ninth month from the beginning of their practical implementation.

In this case, the indicators for assessing the effectiveness of the implementation of measures are given taking into account their projected values as of 01.01.2017, that is, only for 2016 . The list of indicators, for the achievement of the projected values of which in 2018-2020 the State Strategy for Regional Development until 2020 is aimed at, was approved by the Government Resolution of 20.12.2017, that is, at the end of the third year of the six years of its planned implementation.

Thus, the timetable for the preparation, adoption and delivery to the co-executors of national strategic planning decisions was constantly violated and contradicted the tenth principle of the draft law "On State Strategic Planning in 2011", which was to implement the responsibility of participants in state strategic planning for the effectiveness of tasks and measures aimed at achieving the goals of socioeconomic development of the state.

The lack of organization of joint and coordinated development of the State Regional Development Strategy (SRDS) between the central and regional executive bodies has led to the centrifugation of regional goals, priorities and objectives from national ones. This slowed down the processes of state formation in Ukraine and doomed to the degradation of the integral and systemic functioning of the Center and the Regions (Stolyarov, Shinkaryuk, Stolyarova, 2019).

The Decree of the sixth President of Ukraine V. Zelensky "On the Goals of Sustainable Development of Ukraine for the period until 2030" of September 30, 2019 is directed at their activation. The national objectives of the Sustainable Development Goals of Ukraine until 2030 became the reference points for the development of projects, forecast and program documents, statutory instruments, projects of Activity Plans to ensure balanced economic, social and environmental aspects of sustainable development of each region and the state as a whole.

\section{The main results of the research}

\subsection{Challenges and issues of strategic planning}

The Draft State Strategy for Regional Development of Ukraine for the period of 2027 (developed by the Government in 2020) identifies problematic issues that have arisen in the implementation of the Strategy for the period until 2020 (Draft State Strategy for Regional Development until 2027 "Human-centered Development and Unity", 2019):

1. The unpredictability of Strategies' funding sources.

2. Lack of a clear interrelation between strategic and budgetary planning, financial inability to support most of the objectives of the Strategy.

3. Ineffectiveness of existing tools and mechanisms to implement the Strategy.

4. Lack of proper coordination between central and local authorities on the implementation of state regional policy.

5. The actual absence of large-scale regional development projects.

The draft of the State Strategy of Regional Development of Ukraine for the period 2027 (developed by the Government in 2020) also identified problematic issues of implementation and Regional Development Strategies, which may affect the effectiveness of their further implementation and require short-term solutions. These issues as follows:

1) the mismatch between the term of individual regional strategies and Activity Plans for their implementation and the term of the state strategy and Activities Plan for its implementation;

2) the lack of relevant financial resources for most of the objectives of the Regional Development Strategies;

3) excessive detailing of technical specifications for regional development projects, which can be implemented with funds from the State Fund for Regional Development (SFRD);

4) the zone of influence of more than $60 \%$ of the projects does not exceed the size of one locality; 
5) unreasonable overestimation of the cost of the Activities Plan for the implementation of Regional Development Strategies;

6) insufficient funding and its unpredictability;

7) untimely receiving of funds from the state budget to finance the project (including from the State Fund for Rural Development);

8) insufficient level of qualification of project developers;

9) the inability of the winning bidders to ensure the implementation of projects at a high level.

Among the problems of institutional support of the State Strategy for Regional Development and Regional Development Strategies for the period up to 2027, the Government noted the problematic issues of Regional Development Agencies and the System of Monitoring and Evaluation of Implementation of State Regional Policy. That is, the components of state strategic planning that were taken into account in 2017 were left out of consideration, which guided the expert assessment of the Ukrainian Evaluation Association for Policies, Programs and Projects (UEA).

\subsection{The essence and content of strategic planning in a unitary state}

Strategic planning of unitary Ukraine must be based on a new logic of prospective development, which provides for the definition of such strategic goals and strategic priorities and its indicators, which can ensure the replacement of negative trends of the past with positive ones in the future. Strategic planning is carried out according to the following structural and logical scheme: strategic goals - target programs; strategic priorities - strategic development projects; strategic indicators - indicators of Activities Plans.

In Ukraine, as a sovereign, independent, legal, social and unitary state, strategic planning should be carried out using the national methodology for measuring the Regional Human Development Index (RHDI, 2012). The state has had statistical support for RHDI forecast calculations since 2004, after Ukraine joined the global community of the 7 Millennium Development Goals (MDGs) in 2003. The possibility of informational and methodological coordination of RHDI indicators with the MDG indicators has emerged.

The RHDI has been statistically measured since 2004 by 6 block aspects and 33 indicators, of which 22 are development-stimulus indicators and 11 are development-disincentive indicators:

1) reproduction of the population ( 5 indicators, including 4 indicators-stimulators of development, 1 indicator a disincentive of development);

2) social status (6 indicators-disincentives);

3) comfortable life (6 indicators-stimulants);

4) well-being ( 5 indicators, including 4 incentive indicators);

5 ) decent work (6 indicators, including $3 / 3$ );

$6)$ education (5 stimulus indicators).

Extrapolation of objective trends of RHDI components for the prospective planning period reveals the negative predictive dynamics of these components, for which it is necessary to justify strategic priorities and indicators for targeted programs, global and local projects and Activities Plans for their implementation.

In Ukraine, with the depopulation of the nation and catastrophic labor migration, targeted reproduction of the population as a basic aspect of human development, conditioned by the reproduction of human capital, should become the central element of strategic planning of socioeconomic development.

\subsection{System classification of purposeful reproduction processes at different levels of management}

Targeted reproductive processes at different levels of state management of socio-economic development are divided into: national (national economy); regional (administrative organization); sectoral (industries and sectors of the economy, types of economic activity); individual (economic agents of different forms of ownership).

Decentralized budgeting of regional processes of targeted reproduction becomes a leading element of the mechanism of justification of state socio-economic policy, which will be implemented in the relevant State and Regional strategies and Activities Plans for their implementation.

\subsection{Rationale for the limits of budgetary centralism with budgetary federalism}

Among the 25 strategic indicators of the Sustainable Development Strategy "Ukraine 2020", the 17th indicator was defined as follows: in 2020, the share of local budgets will be at least 65 percent of the Consolidated State Budget. 
That is, there are grounds to regulate the financing of socio-economic development of the region at the expense of local budgets in relation to the state budget, using the harmonious proportion of the "Golden Section": 62\% / 38\%. In this case, if $62 \%$ of the Consolidated State Budget for socio-economic development is provided by local budgets, then this is the upper limit of fiscal federalism, and 38\% is the lower limit of fiscal centralism.

The marginal proportions of the "Golden Section" are adequate to the common boundaries of budget centralism and budget federalism, which reflect the level of autonomy and depth of compatibility of purposeful national and regional reproduction processes. Thus, they form the zone of choice of coordinated decisions on the cofinancing of relevant programs, projects and activities in the framework of the social dialogue of national and regional authorities in the amount of $24 \%(62 \%-38 \%=24 \%)$ of the total budget of socio-economic development of the Consolidated Budget of Ukraine. In the conditions of depopulation of the nation, the reform of the financial structure of budgetary unitary expenditures should begin with determining the amount of budgetary funds for the simple reproduction of the available human capital of each region, which should amount to at least 38\% of the Consolidated State Budget for socioeconomic development from local budgets.

Expanded reproduction of human capital of the territory should be provided by the planned increase in the share of local budgets for socioeconomic development to $62 \%$ of the Consolidated State Budget.

The application of a concisely thought-out logical scheme of the planned reform of the budgetary unitary system ensures the achievement of the ratio of distribution of the Consolidated State Budget between the state and local budgets for socio-economic development in accordance with the harmonious proportions of the "Golden Section". This allows the structural harmony of the state budget system to be achieved, which, on the one hand, will ensure consistency and balance of socio-economic interests (relations) of national and regional authorities.

On the other hand, it will become a kind of Generator of raising the level and quality of life of the Ukrainian people in a unitary state, a people fulfilling its planetary mission in the development of European Humanism.

\subsection{Defining the powers of Central and Regional authorities in the strategic planning of a sovereign state}

The powers of Central and Regional authorities in the field of strategic planning are justified on the basis of their role in ensuring the economic cycle and synchronization in the hierarchy and time of the processes of national and regional target reproduction. The level of completeness of the economic cycle of reproduction processes determines the ratio of centralism and autonomy, and the degree of interaction of these processes in simple and expanded reproduction, especially of human capital, determines their compatibility.

The structure of the processes of purposeful reproduction determines the need for their decentralized budgeting in accordance with the expenditure powers of the Central and Regional authorities in the sphere of socio-economic development (Draft State Strategy for Regional Development until 2027 "Human-centered Development and Unity", 2019).

Effective indicators of financial and economic activity of regions and the state as a whole are gross domestic product (GDP) at the national level and gross regional product (GRP) at the regional level. The correlation of the dynamics and share of GRP with the dynamics of GDP will determine the contribution of the corresponding region to the national results.

Ensuring the organic unity of the value and natural form of regional gross output of products and services should take place in the creation of the gross value added (GVA) of the region. The estimation of regional GVA and GDP at the national level should be based on the assumption that GDP is equal to the total GVA of the region taking into account the balance of indirect taxes and subsidies.

Ensuring equality of regions in the distribution of financial resources of socio-economic development in accordance with the contribution to the GDP of a unitary state will be achieved through the use of the principle of justice In accordance with the region's contribution to the country's GDP, its share in the distribution of state financial resources for socio-economic development of the region is determined using the proportions of the "Golden Section" in the Consolidated 
Budget of a unitary state through the principle of harmonization (Stolyarova, 2020).

An alternative to the Decree of Acting President Turchinov O.V. of 14.04.2014 on the opening of the antiterrorist operation (ATO) could be a decision on the transition of Ukraine, as a unitary state, to a model of budgetary federalism with the establishment of financial standards for budget support of the main components of socioeconomic (including human) development of the Luhansk and Donetsk regions.

The Law of Ukraine "On Amendments to the Budget Code of Ukraine (to increase the financial independence of the Autonomous Republic of Crimea and Sevastopol)", which was adopted on 15.04.2014 with the participation of O.V. Turchinov, provides:

- crediting in full to the budget of the Autonomous Republic of Crimea all revenues that are paid (transferred) on the territory of the Autonomous Republic of Crimea and the city of Sevastopol;

- granting the right to local authorities to determine the expenditure of budgetary credit within the income limits without the use of equalization mechanisms, that is, without state interference in the process of forming the budgets of the Autonomous Republic of Crimea and Sevastopol;

- the possibility of distributing inter-budgetary transfers between the budget of the Autonomous Republic of Crimea, the budget of the city of Sevastopol and the relevant local budgets. Taking into account these changes, the budgets of the Autonomous Republic of Crimea and the city of Sevastopol became balanced in terms of revenues and expenditures without a deficit (with a zero transfer from the state budget).

That is, if the so-called annexation of the territory of the Autonomous Republic of Crimea and the city of Sevastopol by the Russian Federation had already taken place at the time of the Decree of Acting President of Ukraine of April 14, 2014 on the beginning of the antiterrorist operation, and, since March 18, 2014, the work of the tax and treasury services in the Ukrainian peninsula was blocked, then cooperation with such services in Luhansk and Donetsk regions was still possible.

The provisions of the Law of Ukraine of 15.04.2014 in the sphere of fiscal policy and increasing financial independence and autonomy of the Autonomous Republic of Crimea and
Sevastopol should be extended to the formation of local budgets of Luhansk and Donetsk regions during the negotiations of the Kiev authorities with the initiators of the People's Republics within the then existing regional and local authorities (12 May 2014 - Luhansk People's Republic and 24 May 2014 - Donetsk People's Republic).

Strategic planning for regional development should not involve financial equalization both vertically and horizontally. Decentralized budgeting is focused on financial provision of strategic goals, priorities, programs and projects from their own sources within the framework of harmonious proportions of the "Golden Section" between the state and local budgets in the consolidated budget of a unitary state.

\section{Conclusions}

The methodological approach to regional strategy and the Center for socio-economic development of regions and the state was implemented by the Khmelnytsky Regional State Administration in 2015-2016.

For the first time in Ukraine, the Regional Human Development Program of Khmelnytsky Region for the period up to 2020 was developed, on the basis of which the Regional Development Strategy of Khmelnytsky Region for 2011-2020 was refined and expanded and the Activities Plan for 2018-2020 from its implementation.

Two new strategic goals were introduced, with the seven Millennium Development Goals defined as operational goals.

Based on statistical data of the Index of Regional Human Development (RHDI) of Khmelnytsky region for 2004-2015 were carried out forecast calculations of 33 of its components on the aspects of the 6th block of RHDI, identifying the negative dynamics of 7 indicators to justify the strategic objectives, priorities and indicators of socio-economic development of Khmelnytsky region for the period up to 2020 .

The regional program of humanitarian and socio-economic development of Khmelnytsky region for 2016-2020, in addition to the tasks to complete the 7 Millennium Development Goals (MDGs) and the implementation of national goals 17 Sustainable Development Goals until 2030, included additional subprograms "Health", "Culture and Arts", "Physical Culture and Sports".

Strategic goals, priorities and indicators of socio-economic development of Luhansk and 
Donetsk regions were determined on the basis of forecast calculations of RHDI constituent regions by 6 block aspects and 33 indicators for 2014-2020, according to statistical data from 2004-2008, 2009-2013.

The system of coordination of targets and indicators of the Millennium Development Goals and Sustainable Development Goals with 6 block aspects and 33 RHDI indicators is substantiated. Based on the results of identifying the negative dynamics of the measurement of individual components of the RHDI, 10 strategic priorities were identified, 9 of which were the same for both regions of the Ukrainian Donbass.

Prospects for further scientific and methodological development are seen in the justification of a coherent "Tree of Development Goals" from United Territorial Communities (UTS) and local governments (LCG) to regional and central executive bodies of administrative regions and the state as a whole.

\section{References:}

Galchinsky, A. S., Geets, V. M., and others (2004). Stratehiia ekonomichnoho ta sotsialnoho rozvytku Ukrainy (2004-2015 roky) "Shliakhom yevropeiskoi intehratsii" [Strategy of economic and social development of Ukraine (2004-2015) "Through European integration"]. Nats. in-t strateh. doslidzh., In-t ekon. prohnozuvannia NAN Ukrainy, M-vo ekonomiky ta $\mathrm{z}$ pytan yevrop. intehr. Ukrainy. Kyiv: IPC of the State Statistics Committee of Ukraine. (in Ukrainian)

Proekt Derzhavnoi stratehii rehionalnoho rozvytku na period do 2027 roku "Rozvytok ta yednist, oriientovani na liudynu" (2019) [Draft State Strategy for Regional Development for the period up to 2027 "Development and unity focused on people"]. Kyiv: Ministerstvo rozvytku terytorii i hromad. (in Ukrainian)

Pro Stratehiiu staloho rozvytku «Ukraina-2020»: Ukaz Prezydenta Ukrainy Petra Poroshenka vid 12 sichnia 2015 roku (2015) [On the Sustainable Development Strategy "Ukraine-2020": Decree of the President of Ukraine Petro Poroshenko of January 12, 2015]. Available at: http://www.kharkivosvita.net.ua/document/4946 (in Ukrainian)

Derzhavna stratehiia rehionalnoho rozvytku na period do 2020 roku (2014) [State strategy of regional development for the period up to 2020]. Available at: https://www.minregion.gov.ua/napryamkidiyalnosti/derzhavna-rehional-na-polityka/strategichne-planuvannya-regionalnogo-rozvitku/ derzhavna-strategiya-regionalnogo-rozvitku-na-period-do-2020-rok/ (in Ukrainian)

Stolyarova, V. V. (2020). Metodolohiia formuvannia kompleksnoho stratehichnoho planuvannia sotsialno-ekonomichnoho rozvytku Ukrainy [Methodology of formation of complex strategic planning of social and economic development of Ukraine]. Upravlinnia ekonomikoiu: teoriia ta praktyka. Chumachenkivski chytannia: zb. nauk. prats / NAN Ukrainy, In-t ekonomiky prom-ti. Kyiv. (in Ukrainian)

Stolyarov, V., Shinkaryuk, O., \& Stolyarova, V. (2019). Kontseptualni polozhennia biudzhetnoho federalizmu v Unitarnii derzhavi Ukraina [Conceptual Provisions of Budget Federalism in the Unitary State Ukraine]. Ekonomichnyi visnyk Donbasu - Economic Bulletin of Donbass, 4(58), 106-110. (in Ukrainian)

Stratehiia staloho rozvytku "Ukraina 2020" (2015) [Sustainable Development Strategy "Ukraine 2020"]. Available at: https://uk.wikipedia.org/ (in Ukrainian)

Annual activity reports (2020). Available at: https://ec.europa.eu>reporting

EU Annual Report on Human Rights and Democracy in the World 2020. Available at: https://reliefweb.int/report/world/eu-annual-report-human-rights-and-democracy-world-2020 